\title{
パピル ス
}

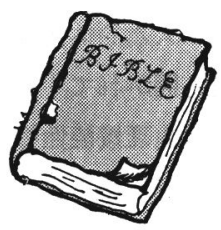

今日の我々の生活のなかで，もはや紙のない生活は考 学られなくなっているといってよい，紙は文明の歴史の なかで最も重要な発明の一つである.今日の紙の原型は 中国の後漢の人，蔡倫によるとされており，西歴 105 年頃であったとするのが通説であった. ところが, 1979 年 12 月, 陝西省での発掘でさらに古い紙が発見され, 通説よりも 150 年汪どさかのぼることになった。

紙のない時代には，石や粘土板，貝がら，骨，象牙， 鉛板, 獣皮, ヤシの葉, 木片, 布などが記録や伝達のメ ディアとして利用されてきた。 しかし，紙の軽さ，丈夫 さ，持ち運びやすさは，ちょっとこれに優るものはな い.

英語で紙をペーパーと呼ぶことは誰でも知っている. このペーパーの語源はエジプトのパピルスに由来し，パ ピルスといえばナイル川がすぐ連想される，パピルスは

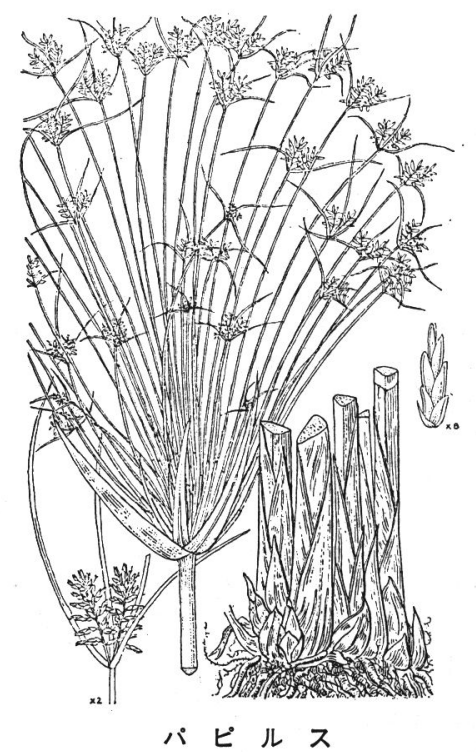

M. Zohary : "Flora Palaestina", Part IV, The Israel Academy of Science and Humanities, Jerusalem, 1985, p. 464 より
エジプトを代表する植物の一つである.

パピルスが聖書に現われるのは, 出エジプト記 2 章 3 節，舞台はやはりナイル川のほとりである.「…....゚ピ ルスで編んだかごを取り，それにアスファルトと樹脂と を塗って，子をその中に入れ，これをナイル川の岸の莘 の中に怙いた……」、へブルびとに男の子が生まれたな らば,ナイル川に投げ込め（同 1 章 22 節）といらェジ プト王パロの命令により生命を奪われる直前, 川浴びに やって来たパ口の娘によってパピルスのしげみから救い 上げられ，王女の子として育てられる. この子こそ, や がて成人したのちエジプトに捕われていたイスラェルの 民を脱出させる指導者となったモーセである．かごに編 まれて，モーセの命を救ら役割を果たしたパピルスは， 古代エジプトの人々にとっては重要な生活資源植物であ り，花穂は神殿の儀式に，茎を編んで綱，扇，サンダ ル, マット, 箱, びんの栓, パピルスの茎の下部の髄は 食料にもなった，茥はサトウキビのように啮んで汁だけ を吸ってはきだす、筆者もかじってみたが，サトウキビ

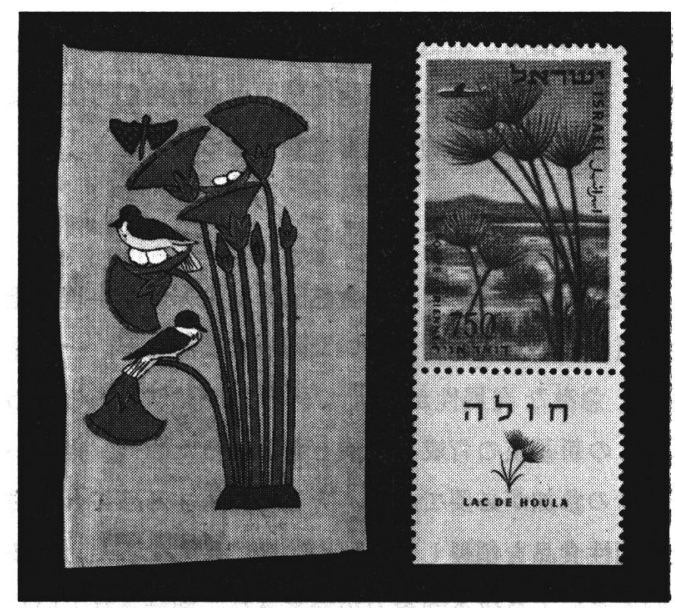

パピルス紙に描かれたパピルスの絵とパピルスを意匠した イスラエルの切手 


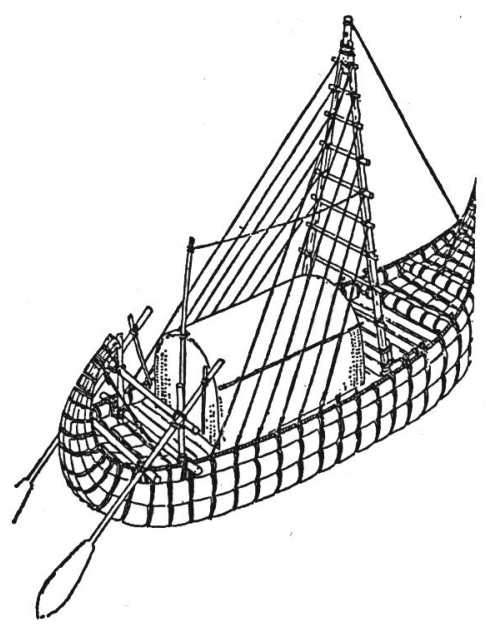

パピルスの船「ラー号」の完成予想図

T. ヘイエルダール著, 永井淳 訳 : “蔁舟ラー号航海記”, 草思社, 1971， p. 157 より.

ほどではないが薄い甘味があった. しかしらまいもので はない. パピルスの茎を使って舟も作られていた. イザ ヤ書 18 章 2 節には,「ああ, エチオピヤの川々のかなた なる，ぶんぶん羽音のする国，この国は莘の船をうか ベ，ナイル川によって使者をつかわす」とある．“莘の 船” とはパピルスの船のことである.このパピルスの船 を再現した人がいる. ノルウェーの文化人類学者へイェ ルダールが, 1970 年, パピルスの船で大西洋の横断を試 み， 2 度目に成功した $\stackrel{5}{\mathrm{R} a}$ 二世号を記憶している方も多 いであろう。ちなみに“Ra”とはエジプトの太陽の名前 に由来している(1).

パピルスが文明にその名をとどめるのは，パピルスを その語源とするペーパーによってである. 下表に示した よらに，各国の紙を示す単語はほとんどがパピルスに由 来していることがわかる.

\section{各国の紙を示す単語}

\begin{tabular}{|c|c|}
\hline paper & (英) \\
\hline papier & (ド, 仏, 蘭, ポーランド) \\
\hline papir & (ノルウェー, デンマーク) \\
\hline papel & (スペイン, ポルトガル) \\
\hline papper & (スェーデン) \\
\hline papiro & （伊） \\
\hline papyrus & (ラテン) \\
\hline$\pi \alpha \pi v \rho o s$ & (ギ) \\
\hline папирус & (ロシヤ) \\
\hline 紙 & （日，中，朝） \\
\hline נִיָר & (ニャール；へブル語） \\
\hline
\end{tabular}

パピルス用ナイフ

古代エジプト新王国時代，洋銀製，ルーブル博物館蔵. $290 \times 13 \mathrm{~mm}$. 復製品

エジプトのパピルスで作られた紙は，ギリシャ・ロー マを中心に広く普及し，商業の中心であったフェニキア のビブロス港から各地に輸出され, やがてビブロス港か らのパピルス紙をビブロスと呼ぶようになり,さらに本 を意味する言葉を経て, Book of Books として Bible と いら言葉ができた.

ペーパーの語源ともなるパピルス紙は, 紙の定義から は紙ではない，紙は水に眯濁させた瀻維を水ごしをし， 薄く平らにからみ合わせて作ったものである. 定義はと もかく，パピルス紙をどうやって作っていたのかはっき りしない.ローマの軍人であり学者でもあった大プリニ ウス (23〜79 年) の『博物誌』13 巻 ${ }^{(2)} に$ 記述がある.「パ ピルス紙は, パピルスの茎の髄を薄く裂き, 薄片とし, これをナイル河の濁り水に浸し, ついで薄片を平板上に 並べ，さらにこれに交叉するように別の薄片をならべ圧 搾してから乾燥する.このままではざらざらして書きに くいので, 象牙や貝がらで表面をこすり平滑にする，薄 片がくっつくのはナイル河の水の泥の粘性説, パピルス の中に含まれる粘性物質説, あるいは別途糊料を使用す る等々の説がある. 濁ったナイル河の水に浸すことに重 要な意味があるとすると, 河水にいる微生物が繁殖した ときに生成する多糖類が一種の“のり”の役目を果たし ているとは考学られなだろらか. 污水を数日間放置す ると容器の内側が妨るとする. いわゆる水の華であ る. そのぬるぬるが接着剤となっているとするとなんと なく納得できる.

1983 年 2 月, 京都で開かれた国際紙会議に出席する ためエジプトからパピルス研究所の H. ラガブ博士が来 日し，パピルス紙の製作を実演して見せてくれた. ラガ ブ博士の意見では, ナイル河の濁水の必要はなく, 真水 でも良いことを強調していた，薄片を一度ローラーで圧 搾してから充分に水を吸わせることが必要であるとい ら. 現在, この方法でェジプトではパピルス紙の復元を 行なっている.

日本でもパピルス紙の復元に情熱をもやす人がいる. 


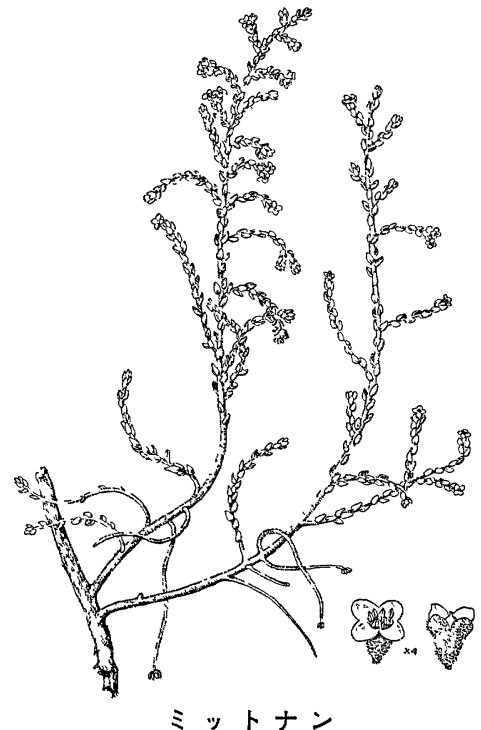

M. Zohary : "Flora Palaestina", Part II, The Israel Academy of Science and Humanities, Jerusalem, 1972, p. 487 より

大沢忍氏で,『パピルス紙の秘密, 復元の研究』(みすず 書房，1978）を出版しておられる: また，季刊『銀花』 第 42 号（1980）には安土孝 氏の「パピルスの栽培から 製本まで」といら記事がありこのパピルス紙を使っ て童話作家の武井武雄 氏が『ナイルの蔁』という本に 仕立たことが載っている. 新しいところでは遠藤紀勝 氏 の「パピルス紙が語る古代エジプト」（百万塔 64 号， 35 頁 (1986)）に復元の試みが，矢島・遠藤 著『死者の書 一一古代エジプトの遣産パピルス』（社会思想社，1986） がある. 後者はちょっと高価だけれども，カラフルで見 て楽しめる本である、おまけとしてパピルス復元キット が付いている.

聖書がパピルス紙に書かれたことでパピルスが有名に なったのだが，最近，イスラェルでは，パピルス紙では なく新しい紙としてミットナン (Thymelaea hirsuta； ジンチョウゲ科）の樹皮から雁皮，三椏と同じ方法で製 紙が試みられていることにふれて执く(3). ミットナンと 呼ばれるこの灌木から，ネゲブ砂漠(イスラェル南部)の ベドウィン族はロープを作り、ラクダをつないだりする のに用いる. この植物には $C$-グリコシドフラボンとし $\tau, 6,8$-di- $C-\beta$-D-glucopyranosyl apigenin ${ }^{(4)}$, Daphnoretin ${ }^{(5)}$ ，Resiniferonol 誘導体 ${ }^{(6)}$ が含をれておゔり，毒性 があるため動物が口にしないので，つなぎとめたりする

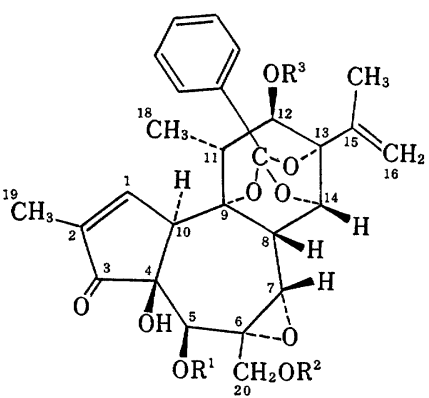

\begin{tabular}{llll}
\multicolumn{1}{l}{ 化合物 $\mathrm{R}^{1}$} & $\mathrm{R}^{2}$ & $\mathrm{R}^{3}$ \\
\hline 1 & $\mathrm{H}$ & $\mathrm{H}$ & $\mathrm{OC}-\mathrm{CH}=\mathrm{CH}-$ \\
2 & $\mathrm{H}$ & $\mathrm{H}$ & $\mathrm{OC}-\mathrm{CH}=\mathrm{CH}-\left(\mathrm{CH}_{2}\right)_{13} \mathrm{CH}_{3}$ \\
3 & $\mathrm{H}$ & $\mathrm{H}$ & $\mathrm{H}$ \\
4 & $\mathrm{OC}-\mathrm{CH}_{3}$ & $\mathrm{O}-\mathrm{CH}_{3}$ & $\mathrm{OC}-\mathrm{CH}_{3}$
\end{tabular}

Resiniferonol 誘渞体

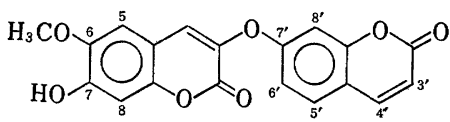

Daphnoretin

のに好都合なのであろう．何でも喰べる黒やぎもこの灌 木は喰べない。

映画や歌劇にもなっているので知っている方も多いと 思らが,「サムソンとデリラ」(7) の物語は怪力の勇士が愛 人デリラの計略にはめられペリシテ人に捕えられるので あるが，彼をしばったのはこの樹の樹皮から作ったロー プだといわれている、サムソンをしばるには強勒なミッ トナンの纎維が必要といらことであろうか.

パピルスを見たことのない人は，東京の王子駅前の紙 の博物館の入口, 名古屋市東山植物園, 岡山大学薬学部 薬草園, 鳥取大学農学部附属農場などで栽培されてい る、最近は園芸店でも時々見かけるようになった。

1） T.ヘイエルダール著, 永井淳訳 : “葦舟ラー号航海記”, 草思社, 1971.

2）中野定雄ら訳 : “プリニウスの博物誌II”，雄山閣，1985, p. 578.

3) J.Schmidt \& N. Stavisky: 'Uses of Thymelaea hir. suta (Mitnan) with emphasis on hand papermaking', Economic Botany, 37, 310 (1983).

4) M. A. M. Nawwar et al.: Phytochemistry, 16, 1319 (1977).

5) A. M. Rizk et al.: ibid, 11, 473 (1972).

6) A. M. Rizk et al : Experientia, 40, 808 (1984).

7）旧約聖書士師記 13 章 24 節〜16 章 35 節, サンサーンス (1835 1921)：歌劇サムソンとデリラ，1877年作曲.

(中島 路可, 鳥取大学工学部工業化学科) 